\title{
PELATIHAN PENGGUNAAN APLIKASI LAPOR KEPADA KOMUNITAS PEMUDA UNTUK MENINGKATKAN PARTISIPASI MASYARAKAT
}

\author{
Muhammad Quranul Kariem¹) \\ 1)Program Studi IImu Pemerintahan, Fakultas IImu Pemerintahan dan Budaya, Universitas Indo Global Mandiri, \\ Palembang, Sumatera Selatan, Indonesia \\ Corresponding author : Muhammad Quranul Kariem \\ E-mail : mquranul@uigm.ac.id
}

Diterima 30 Juli 2021, Direvisi 02 Agustus 2021, Disetujui 03 Agustus 2021

\begin{abstract}
ABSTRAK
Keterlibatan masyarakat untuk ikut turut serta dalam pengawasan organisasi publik sangat penting untuk meningkatkan akuntabilitas dan transparansi pemerintah, dalam rangka menjalankan pemerintahan yang efektif. Pelatihan penggunaan aplikasi lapor menjadi salah satu alternatif untuk meningkatkan partisipasi masyarakat tersebut. Sasaran mitra pelatihan ini adalah komunitas pemuda demokrasi Palembang, pelatihan ini dilaksanakan menggunakan metode daring dengan melakukan pretest dan post-test untuk menunjukkan hasil pelatihan yang dilakukan. Peserta pelatihan pada umun-nya belum mengetahui dan belum memahami cara teknis penggunaan aplikasi tersebut. Hasil pelatihan menunjukkan terdapat peningkatan pengetahuan dan ketrampilan teknis penggunaan aplikasi lapor yang cukup signifikan. Hal tersebut akan berdampak pada peningkatan partisipasi masyarakat, khususnya generasi muda untuk dapat menggunakan aplikasi lapor sebagai media penyampaian aspirasi dan pengaduan yang resmi.
\end{abstract}

Kata kunci: aspirasi; pengaduan; lapor

\section{ABSTRACT}

Community involvement to participate in the supervision of public organizations is very important to increase government accountability and transparency, in order to run an effective government. Training on the use of the report application is one alternative to increase community participation. The target of this training partner is the Palembang democracy youth community, this training is carried out using an online method by conducting pre-test and post-test to show the results of the training carried out. The trainees in general do not know and do not understand the technical way of using the application. The results of the training showed that there was a significant increase in knowledge and technical skills in the use of reporting applications. This will have an impact on increasing community participation, especially the younger generation to be able to use the report application as a medium for formally submitting aspirations and complaints.

Keywords: aspiration; complain; report

\section{PENDAHULUAN}

Dengan tujuan Pemerintahan yang demokratis harus bersedia membuka diri untuk dapat meningkatkan efektifitas dalam menjalankan tugas dan fungsinya. Paradigma tersebut seharusnya dapat dilaksanakan dalam negara yang menggunakan bentuk pemerintahan yang demokratis. Keterbukaan pemerintahan dapat ditunjang dengan partisipasi aktif masyarakat dalam setiap kegiatan pemerintahan. Pemerintah dan DPR merupakan institusi penyelenggara pemerintahan, dimana institusi tersebut bekerja berdasarkan kesepakatan dan kehendak masyarakat.

Hasil dari kerja dari penyelenggara pemerintahan adalah kebijakan publik yang diharapkan akan menunjang pembangunan dan mengentaskan persoalan masyarakat. Namun, seringkali dibalik wewenang yang dimiliki untuk merumuskan dan melaksanakan kebijakan publik, terdapat oknum-oknum pemerintahan yang tidak bertanggungjawab yang menyalahgunakan wewenang yang dimiliki tersebut (adanya potensi abuse of power). Maka dari itu, keterlibatan masyarakat dalam urusan-urusan pemerintahan dengan cara ikut mengawasi dan berpartisipasi secara langsung atau tidak langsung sangat penting untuk mereduksi potensi penyalahgunaan kekuasaan itu.

Pemerintah merilis aplikasi berbasis internet (web) bernama aplikasi lapor.go.id, sebagai sarana untuk melibatkan masyarakat dalam pelaksanaan pemerintahan. Aplikasi tersebut dikelola oleh tiga institusi, yaitu 
Kementerian Pendayagunaan Aparatur Negara dan Reformasi Birokrasi, Kantor Staf Kepresidenan, dan Ombudsman Republik Indonesia (tirto.id, 2020). Aplikasi tersebut merupakan aplikasi yang terintegrasi secara nasional, yang diharapkan mampu meningkatkan akuntabilitas dan transparansi didalam institusi pemerintahan.

Dalam era perkembangan teknologi informasi seperti saat ini, pengguna internet di indonesia semakin mengalami peningkatan setiap tahun. Tercatat, pengguna internet di Indonesia mencapai 202,6 juta jiwa pada tahun 2021 , mengalami peningkatan $15,5 \%$ dari tahun sebelumnya (kompas.com, 2021). Berdasarkan data yang dirilis oleh statista pada tahun 2020 yang lalu, pengguna internet di Indoensia adalah mayoritas pemuda berusia 25-34 tahun dan 18-24 tahun (katadata.co.id, 2020). Hal ini menjadi peluang dan tantangan untuk meningkatkan keterlibatan masyarakat, khususnya pemuda dalam penyampaian aspirasi dan pengawasan di organisasi pemerintahan.

Generasi muda harusnya mampu mengawali dan mendorong partisipasi masyarakat dalam pemerintahan, oleh karena itu diperlukan pemahaman yang komprehensif mengenai pentingnya penyampaian aspirasi dan pengawasan kepada organisasi pemerintahan. Kajian yang dilakukan Hediansyah, dkk (2018) menyebutkan bahwa sosialisasi kepada kelompok-kelompok pemuda di jatinagor berdampak pada tercapainya kesepakatan untuk mencerdaskan para pemilih dalam pemilu. Hal yang sama juga terjadi di desa moluo di Kabupaten Gorontalo Utara, dimana setelah mendapatkan sosialisasi, pemuda di desa tersebut memiliki pemahaman dan kesadaran untuk secara aktif turut ikut andil dalam pembangunan desa (Ngiu, dkk, 2021).

Selanjutnya, metode penyuluhan yang dilakukan kepada pemuda karang taruna sekecamatan panyingkiran, efektif untuk meningkatkan pengetahuan, pemahaman, dan wawasan serta kesadaran berpolitik (Kuswati, 2019). Penggunaan edukasi juga dilakukan untuk memberikan edukasi kepada kelompok pemuda di palembang, dimana hasilnya menunjukkan adanya peningkatan pengetahuan di bidang pengawasan organisasi publik (Kariem \& Alief, 2020). Berbagai kajian yang telah diuraikan menunjukkan bahwa generasi muda dapat ditingkatkan kemampuan, kesadaran, dan partisipasinya dalam ikut adil dalam pemerintahan dengan menggunakan berbagai metode edukasi. Oleh karena itu, penting-nya memberikan pemahaman dan kemampuan teknis bagi komunitas muda untuk dapat menggunakan aplikasi lapor dalam rangka meningkatkan partisipasi masyarakat.

Komunitas pemuda yang akan menjadi sasaran dalam kegiatan pengabdian masyarakat ini adalah komunitas pemuda demokrasi palembang. Komunitas tersebut melakukan diskusi dan kajian mengenai fenomena demokrasi di palembang dan sekitarnya, sehingga cukup tepat untuk diberikan pelatihan mengenai penggunaan aplikasi lapor.go.id dalam rangka meningkatkan kapasitas organisasi tersebut.

\section{METODE}

Metode yang digunakan dalam pengabdian masyarakat ini adalah metode pelatihan yang dilakukan secara daring (online) dengan metode tidak langsung (unsinkronus). Peserta dikumpulkan dalam satu grup pelatihan menggunakan platform whatsapp. Instruktur memberikan ketentuan mengenai pelatihan yang akan dilaksanakan. Pelatihan dilakukan untuk komunitas pemuda demokrasi palembang yang mengikuti pelatihan melalui video yang telah dipersiapkan di youtube, yang dibagikan ke dalam grup pelatihan tersebut, namun sebelumnya peserta pelatihan wajib mengisi absensi dan pre-test untuk melihat pemahaman awal mengenai penggunaan aplikasi lapor. Setelah itu peserta mengikuti video pada link yang sudah dipersiapkan, dan mengisi post-test setelah-nya untuk mengukur pemahaman yang didapatkan setelah pelatihan dilakukan. Mitra merupakan komunitas pemuda demokrasi palembang, yang melakukan kajian dan penelitian mengenai demokrasi. Pelatihan dilaksanakan pada 22 Juli 2021 pada pukul 15.00-17.00 WIB.

\section{HASIL DAN PEMBAHASAN}

Komunitas pemuda demokrasi palembang yang mengikuti pelatihan ini, terlebih dahulu mengisi pre-test yang telah dipersiapkan dalam google formulir secara daring. Terkait dengan keberadaan aplikasi lapor.go.id yang telah dirilis oleh pemerintah beberapa tahun yang lalu, sebanyak $45,5 \%$ responden menyatakan belum mengetahui keberadaan aplikasi tersebut. Angka ini cukup tinggi, mendekati separuh peserta pelatihan tidak mengetahuinya, hal ini menjadi realitas yang kurang baik, mengingat pengguna internet yang sebagian besar adalah generasi muda seperti yang telah diuraikan sebelumnya, seharusnya bisa mendapatkan informasi yang lebih banyak dari generasi yang lebih tua. Data selanjut-nya menunjukkan bahwa $100 \%$ responden tidak pernah menggunakan aplikasi lapor.go.id. Kondisi ini menunjukkan dan mengkonfirmasi data sebelumnya, bahwa 
terdapat responden yang mengetahui aplikasi tersebut dan tidak pernah menggunakan-nya.

Banyak faktor yang menjadi penyebab dari tingginya peserta pelatihan yang mengetahui, namun tidak pernah menggunakan aplikasi tersebut, diantaranya adalah masalah teknis penggunaan, dimana sebanyak $54,5 \%$ responden menyatakan tidak mengetahui cara penggunaan-nya. Data selanjut-nya menunjukkan bahwa 36,4\% responden pernah mengalami masalah dalam pelayanan publik yang diberikan pemerintah. Peserta pelatihan yang pernah mengalami masalah pelayanan publik hampir mayoritas, sebanyak 90,9\% ingin mengadukan masalah tersebut kepada pihak yang berwenang. Responden juga secara menyeluruh ingin menyampaikan aspirasi kepada pemerintah dan menganggap bahwa aspirasi masyarakat kepada pemerintah itu penting.

Pelatihan dilakukan dengan menyampaikan pengantar mengenai pentingnya partisipasi masyarakat dalam bentuk pengawasan dan penyampaian aspirasi untuk menciptakan pemerintahan yang efektif melalui kebijakan publik yang berorientasi pada kepentingan masyarakat. Selain itu terdapat setidaknya lima manfaat penyampaian aspirasi dan pengaduan oleh masyarakat, yaitu pertama adalah terciptanya kebijakan yang sesuai dengan kehendak masyarakat, kedua adalah dapat meminimalisir penyalahgunaan kekuasaan, ketiga adalah dapat menciptakan pemerintahan yang demokratis, keempat adalah meningkatkan akuntabilitas dan transparasi dalam institusi pemerintahan, dan yang kelima adalah meningkatkan kinerja pemerintahan. Penggunaan aplikasi lapor diawali dengan membuka aplikasi tersebut pada perangkat laptop atau ponsel dan menuliskan alamat web di www.lapor.go.id, selanjutnya masuk mendaftar menggunakan alamat surel google yang dimiliki.

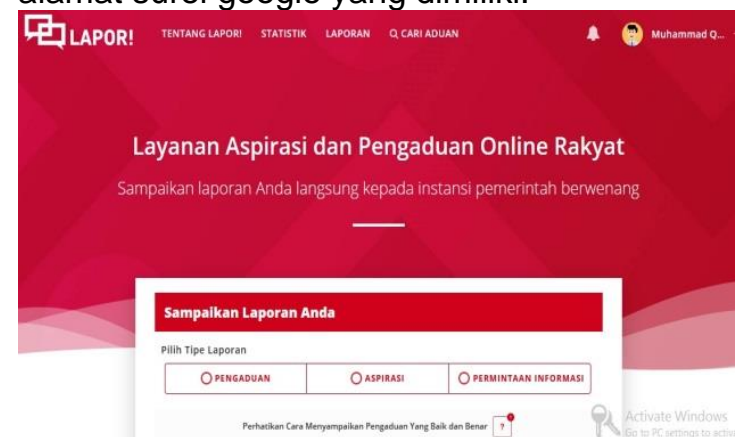

Gambar 1. Tampilan web Aplikasi Lapor

Tahap selanjut-nya adalah memilih tipe laporan, terdapat tiga tipe laporan yaitu pengaduan, aspirasi, dan informasi publik. Pertama, untuk tipe laporan pengaduan digunakan untuk menyampaikan hal-hal yang dianggap merugikan masyarakat terkait dengan pelayanan publik. Pelapor harus menuliskan judul laporan yang merupakan intisari dari laporan yang dituliskan. Pelapor kemudian menuliskan isi laporan dengan menyampaikan identitas nama lengkap dan nomor induk kependudukan yang dimiliki terlebih dahulu, selanjut-nya memilih tanggal kejadian dan lokasi kejadian.

Pelapor juga harus menentukan instansi mana yang akan dituju terkait pengaduan yang dibuat. Peserta pelatihan dalam hal ini diberikan pemahaman mengenai berbagai instansi pemerintahan, agar dapat memahami instansi mana yang mempunyai otoritas atau yang dapat dipilih terkait pengaduan yang dibuat. Pemahaman mengenai intansi pemerintahan menjadi sangat penting, mengingat pengaduan yang disampaikan haruslah sesuai dengan instansi yang menyediakan pelayanan publik bagi masyarakat.

Pelapor juga harus dapat menentukan kategori-kategori laporan yang telah ditentukan dalam aplikasi tersebut, dan terakhir mengunggah lampiran yang relavan dengan laporan yang dibuat. Pelapor selanjutnya memilih apakah identitas-nya bersifat rahasia atau tanpa nama (anonim) atau kedua-nya. Terakhir, klik pada tombol lapor apabila semua daftar isian telah diisi sebagaimana mestinya. Laporan yang disampaikan oleh pelapor, akan diverifikasi selama tiga hari kerja terhadap instansi terkait, dilanjutkan dengan tahap proses tindak lanjut oleh institusi terkait dengan waktu lima hari kerja. Setelah tiga tahapan tersebut, pelapor memberikan tanggapan hasil tindak lanjut laporan yang disampaikan selama sepuluh hari kerja, apabila belum ada penyelesaian yang memuaskan, laporan akan ditindaklanjuti hingga terselesaikan.

Pada bagian aspirasi, pemohon dapat menuliskan judul aspirasi yang berupa inti dari aspirasi yang akan disampaikan. Pemohon selanjutnya dapat menuliskan aspirasi dengan menuliskan nama dan nomor induk kependudukan terlebih dahulu, dan menarasikan aspirasi yang hendak disampaikan. Kemudian, pemohon mengisikan asal daerah dan instansi tujuan untuk dapat menindaklanjuti aspirasi yang disampaikan. Terakhir, pemohon menuliskan kategori aspirasi dan mengunggah lampiran apabila ada, dan memilih tombol lapor. Tahapan mengenai aspirasi yang disampaikan oleh pemohon sama dengan tahapan mengenai pengaduan pada situs lapor.go.id.

Pelatihan yang dilaksanakan berdampak pada beberapa aspek terhadap peserta pelatihan berdasarkan post-test yang 
dilakukan setelah pelatihan, yaitu pertama terkait dengan pengetahuan responden mengenai aplikasi lapor.go.id yang sebelumnya hanya $54,5 \%$ meningkat menjadi $100 \%$. Pengetahuan mengenai aplikasi lapor.go.id menjadi modal awal untuk dapat berpartisipasi aktif dalam menyampaikan pengaduan dan aspirasi kepada pemerintah. Peningkatan signifikan juga terjadi pada aspek cara penggunaan aplikasi lapor secara teknis, terjadi peningkatan sebanyak $45,5 \%$ responden terampil menggunakan aplikasi tersebut.

Pengetahuan mengenai cara teknis penggunaan aplikasi sangat penting, karena hal tersebut dapat menunjang peningkatan kualitas pengaduan dan aspirasi yang disampaikan, dan berdampak pada meningkat-nya peluang untuk dapat diproses secara cepat. Peserta pelatihan yang sebelumnya mengalami masalah terkait dengan pelayanan publik yang diberikan pemerintah namun tidak mengetahui cara menyampaikan pengaduan-nya, saat ini terjadi peningkatan sebesar $63,6 \%$ peserta pelatihan ingin mengadukan masalah terkait dengan pelayanan publik tersebut.

Berbagai aspek mengenai penggunaan aplikasi lapor.go.id untuk meningkatkan pemahaman komunitas pemuda demokrasi palembang dalam menyampaikan pengaduan dan aspirasi memang sangat penting untuk dilakukan, mengingat hal tersebut menjadi modal dasar untuk berparitipasi dalam pengawasan pemerintah. Kendala yang dihadapi selama ini adalah informasi dan cara penggunaan aplikasi tersebut secara teknis, serta kurangnya pemahaman mengenai pentingnya peran serta masyarakat dalam melakukan pengawasan dan menyampaikan aspirasi terhadap organisasi pemerintah. Keterlibatan seluruh elemen masyarakat, terutama generasi muda yang mampu menguasai teknologi informasi akan sangat membantu untuk mengakselerasi partisipasi masyarakat tersebut.

\section{SIMPULAN DAN SARAN}

Komunitas pemuda demokrasi palembang yang awalnya tidak benar-benar mengetahui urgensi dari pengawasan publik terhadap organisasi pemerintah, saat ini menjadi lebih memahami hal tersebut. Pelatihan aplikasi lapor yang diberikan berdampak pada peningkatan pengetahuan yang cukup siginifikan, hal tersebut juga mendorong keinginan peserta pelatihan untuk menyampaikan pengaduan dan aspirasinya kepada pemerintah terkait. Selain itu, pemahaman mengenai teknis cara penggunaan aplikasi lapor juga mengalami peningkatan yang baik berdasarkan perbandingan pre-test dan post-test yang telah dilakukan. Oleh karena itu, pelatihan menggunakan aplikasi lapor untuk meningkatkan partisipasi masyarakat khususnya generasi muda, dalam hal penyampaian pengaduan dan aspirasi cukup efektif.

Rekomendasi selanjut-nya, selain memberikan pemahaman mengenai urgensi pengawasan instansi pemerintah oleh masyarakat, serta pemahaman mengenai teknis cara penggunaan aplikasi lapor.go.id, agar dapat dilaksanakan pelatihan untuk dapat meningkatkan kualitas pengaduan dan laporan, yang akan semakin membuat pemerintah dapat merespon pengaduan dan laporan tersebut dengan cepat dan tepat.

\section{DAFTAR RUJUKAN}

Herdiansah, A. G., dkk (2018). PARTISIPASI GENERASI MUDA DALAM

MEMBENTUK MASYARAKAT PEMILIH YANG CERDAS DAN DEWASA BERPOLITIK DI KECAMATAN JATINANGOR. Dharmakarya, 7(4), 252-256.

Kariem, M. Q., \& PAG, M. A. A. (2021). Edukasi Pengawasan Organisasi Publik bagi Kelompok Pemuda di Palembang. Jurnal Abdimas Mahakam, 5(01), 7480.

Kuswati, Y. (2019). PENYULUHAN PENDIDIKAN POLITIK BAGI PEMILIH PEMULA KARANG TARUNA KECAMATAN PANYINGKIRAN. JURNAL PARAHITA ABDIMAS Jurnal Pengabdian Masyarakat, 1(1), 52-62.

Ngiu, Z., Wantu, A. W., \& Djafar, D. R. (2021). Sosialisasi Pembinaan bagi Pemuda dalam Pembangunan Desa di Desa Moluo Kecamatan Kwandang Kabupaten Gorontalo Utara. Jurnal Abdidas, 2(2), 420-423.

Mengenal Aplikasi LAPOR! dan Cara Kirim Laporan Warga ke Pemerintah, diakses : https://tirto.id/mengenalaplikasi-lapor-dan-cara-kirim-laporanwarga-ke-pemeritah-f2ZH

Jumlah Pengguna Internet Indonesia 2021 Tembus 202 Juta, diakses https://tekno.kompas.com/read/2021/0 2/23/16100057/jumlah-penggunainternet-indonesia-2021-tembus-202juta?nomgid=1

Berapa Usia Mayoritas Pengguna Media Sosial di Indonesia ? diakses https://databoks.katadata.co.id/datapu blish/2020/11/23/berapa-usiamayoritas-pengguna-media-sosial-diindonesia 